\title{
New Pea (Pisum sativum L.) Accesions Obtained at V.R.D.S. Buzau
}

\author{
Costel VÎNĂTORU ${ }^{1}$, Bianca ZAMFIR ${ }^{1}$, Camelia BRATU ${ }^{1}$ \\ ${ }^{1}$ Vegetable Research and Development Station Buzău, No. 23, Mesteacănului Street, zip code 120024, \\ Buzău, Romania \\ *)Corresponding author, e-mail: costel_vinatoru@yahoo.com
}

BulletinUASVM Horticulture 73(2) / 2016

Print ISSN 1843-5254, Electronic ISSN 1843-5394

DOI:10.15835/buasvmcn-hort:12085

\begin{abstract}
Climatic conditions are favourable for cultivation of pea (Pisum sativum) throughout our country. Development of new valuable varieties in this species, with high yield capacity and high quality, with different periods of maturation in order to reschedule over a long period of time may enhance cultivation of this crop.
\end{abstract}

Keywords: earliness, genotype, Getica, phenotype, pods

\section{Introduction}

Climatic conditions are favourable for cultivation of pea (Pisum sativum) throughout our country. Pea entered Europe in its southeast regions and progressed into its interior via Danube. (Ljuština, 2010) Concerns for growing this species at V.R.D.S.Buzau existed since the establishment (1957). The assortment of varieties has been recently enriched with a new protected variety named Getica. Pea was the original model organism used in Mendel's discovery (1866) of the laws of inheritance, making it the foundation of modern plant genetics. (Smýkal, 2012). Pulses, including peas, have long been important components of the human diet due to their content of starch, protein and other nutrients. (Dahl, 2011)

\section{Aims and objectives}

Increasing the varietal diversity with new valuable varieties in this species, with high yield capacity and high quality, with different periods of maturation in order to reschedule over a long period of time.

\section{Materials and methods}

Researches started with collecting germplasm in this species resulting in a collection of 31 genotypes. As control variety in evaluating and sorting the material used for variety improvement was used the well-known variety Getica. After evaluating this collection four genotypes were selected (L1,L2,L3,L4). Breeding method used was recurrent individual selection. The crop was set on March $17^{\text {th }}$ on molded field using $140 \mathrm{~cm}$ four foot-way and $94 \mathrm{~cm}$ at crest following this seeding scheme (Fig.1.).

\section{Results and discussion}

The outcome of the research resulted in the selection of four new accessions which show different maturity ages; the earliest was L1 that reached technical maturity on June 1 and the latest was $L 4$ that reached technical maturity in June 25. The control variety matured on June 5 . The first selection in reaching physiological maturity was L1 on 20.06 and L4 was latest reaching physiological maturity on 19 July (Tab. 1.)

In terms of plant height, L4 was the most vigorous with $105 \mathrm{~cm}$ and L3 showed a dwarf port with an average height of $56 \mathrm{~cm}$. L2 presented the highest number of shoots (4). Concerning the shoots length, L4 presented an average length of $68 \mathrm{~cm}$ and most short shoots were found in L1 with $19 \mathrm{~cm}$. In terms of the number of leaves per plant, 


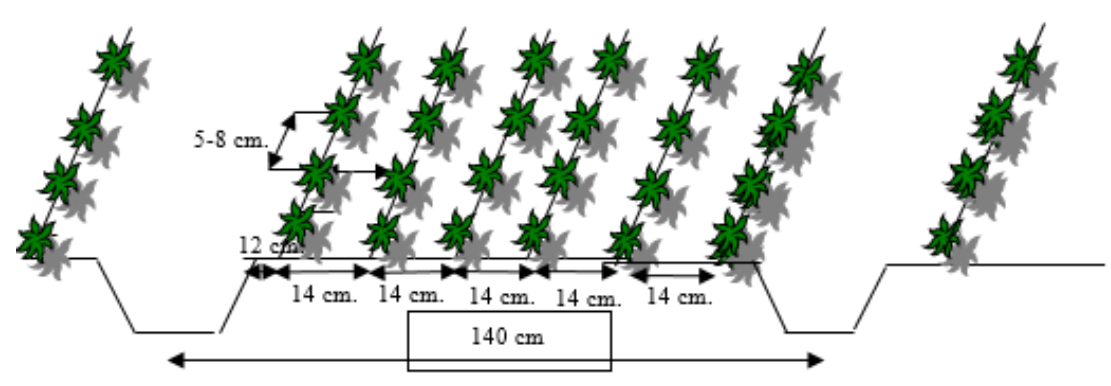

Fig.1. Seeding scheme on molded field

Tab.1. Main phenological data of the pea materials evaluated

\begin{tabular}{ccccccc}
\hline Accession & Seed date & Sprout date & Blooming date & Technical maturity & Physiological maturity & Maturity group \\
\hline C.v.Getica & 17.03 & 8.04 & 3.05 & 5.06 & 25.06 & 0.1 early \\
\hline A1 & 17.03 & 8.04 & 1.05 & 1.06 & 20.06 & 0.1 early \\
\hline A2 & 17.03 & 8.04 & 23.05 & 18.06 & 10.07 & 03semilate \\
\hline A3 & 17.03 & 8.04 & 3.05 & 12.06 & 30.06 & 02 semi early \\
\hline A4 & 17.03 & 8.04 & 16.05 & 25.06 & 19.07 & 03 late \\
\hline
\end{tabular}

Tab. 2. Main plants characteristics for the pea materials evaluated

\begin{tabular}{cccccc}
\hline Accession & $\begin{array}{c}\text { Plants height } \\
(\mathrm{cm})\end{array}$ & Shoots no. & $\begin{array}{c}\text { Shoots lenght } \\
(\mathrm{cm})\end{array}$ & Leaves no. & $\begin{array}{c}\text { Internodal } \\
\text { distance }(\mathrm{cm})\end{array}$ \\
\hline C. v. Getica & 82 & 3 & 22 & 24 & 6,2 \\
\hline A1 & 64 & 3 & 19 & 16 & 7,4 \\
\hline A2 & 74 & 4 & 16 & 19 & 8,2 \\
\hline A3 & 56 & 3 & 46 & 34 & 5,6 \\
\hline A4 & 105 & 3 & 68 & 22 & 8,8 \\
\hline
\end{tabular}

Tab. 3. Main pods characteristics for the pea materials evaluated

\begin{tabular}{ccccccccc}
\hline Accesion & $\begin{array}{c}\text { No. of } \\
\text { pods/plant }\end{array}$ & $\begin{array}{c}\text { Pod lenght } \\
(\mathrm{cm})\end{array}$ & $\begin{array}{c}\text { Pod } \\
\text { diameter } \\
(\mathrm{cm})\end{array}$ & $\begin{array}{c}\text { Pod weight } \\
(\mathrm{g})\end{array}$ & $\begin{array}{c}\text { Total/ } \\
\text { plant(g) }\end{array}$ & $\begin{array}{c}\text { Grains no./ } \\
\text { pod }\end{array}$ & $\begin{array}{c}\text { Grains } \\
\text { weight/ } \\
\text { pod(g) }\end{array}$ & $\begin{array}{c}\text { Total } \\
\text { weight of } \\
\text { grains/ } \\
\text { plant(g) }\end{array}$ \\
\hline C.v.Getica & 16 & 7.4 & 1.2 & 7.5 & 120 & 8 & 3.9 & 62.4 \\
\hline A1 & 18 & 7.7 & 1.4 & 7.7 & 138.6 & 8 & 5.7 & 102.6 \\
\hline A2 & 13 & 10.8 & 1.2 & 7.8 & 101.4 & 10 & 5.9 & 76.7 \\
\hline A3 & 32 & 7.5 & 1.3 & 5.2 & 166.4 & 6 & 3.4 & 108.8 \\
\hline A4 & 26 & 6.8 & 1.0 & 4.8 & 124.8 & 8 & 2.9 & 75.4 \\
\hline
\end{tabular}

L3 with 34 leaves and L1 ranked first presented a total of 16 leaves / plant, with a low foliage. Regarding the distance between internodes, the smallest distance was recorded in L3 with $5.6 \mathrm{~cm}$ and the highest value was recorded in L4 with 8.8 cm. (tab.2.)
Concerning the number of pods per plant, the first place was registered by L3 with 32 pods / plant and the lowest value was 13 pods at L2 and the control variant recorded an average yield of 16 pods / plant. In terms of pod length, the highest value was recorded by L2 with $10.8 \mathrm{~cm}$ and the lowest value was $6.8 \mathrm{~cm}$ registered by $\mathrm{L} 4$. 
Regarding pods / plant yield, L3 stood first with $166.4 \mathrm{~g}$ and the lowest value was recorded by L2 with $101.4 \mathrm{~g}$, below the value of control variety which achieved $120 \mathrm{~g}$ total yield. Regarding the total weight of grains / plant at technical maturity, all 4 lines exceeded the control variety, first being L3 with $108.8 \mathrm{~g}$ followed by L1 with $102.6 \mathrm{~g}$ and the control variant recording a yield of $62.4 \mathrm{~g} /$ plant.(Table.3.)

\section{Conclusion}

We conducted and evaluated a valuable germplasm collection that can be harnessed to improve future research work. Also four new varieties with distinct characteristics and different ripening periods have been selected; these materials that will be proposed for patenting. The results received after promoting new creations among farmers by distributing promotional biological material (seeds), are very positive.

\section{REFERENCES}

1. Ljustina, Marija, and Aleksandar Mikic. (2010)."A Brief Review on the Early Distribution of Pea (Pisum sativum L.) in Europe." Field \& Vegetable Crops Research 47.2.

2. Smýkal, Petr, et al. (2012): "Pea (Pisum sativum L.) in the genomic era." Agronomy.

3. Wendy J. Dahl, Lauren M. Foster and Robert T. Tyler (2012). Review of the health benefits of peas (Pisum sativum L.). British Journal of Nutrition, 108, pp S3-S10. doi:10.1017/S0007114512000852. 13 December 2011). 